\title{
Fra kulturformidling til kulturmødesteder: Social interaktion med kommunikationsnetværk
}

\author{
Af Roy Langer
}

Networks matter because they are the underlying structure of our lives. Manuel Castells, 2004, s. 224

\begin{abstract}
Denne artikel har til formål at præsentere en sociologisk og kommunikationsteoretisk forståelsesramme for kulturinstitutioners arbejde $i$ et $i$ stigende grad fragmenteret samfund ved at fokusere på netværkskommunikation. Artiklen udfordrer kulturinstitutioners traditionelle, oftest politisk definerede (men samtidig ofte internaliserede) rolleforståelse som (envejs-)kulturformidlere $\mathrm{i}$ integrationen af kulturelle minoriteter. I stedet foreslås, med afsæt $\mathrm{i}$ netværkstilgangen, en forståelse af kulturinstitutioner som kulturmødesteder, der er forankret i og interagerer med diverse minoritetsnetværk for at bidrage til en gensidig kulturtilpasning. Der argumenteres for, at en sådan forståelse på længere sigt også rummer bedre argumenter til at beskytte og øge disse institutioners egen legitimitet.
\end{abstract}

\section{Indledning}

Biblioteker, museer, arkiver og andre offentlige kulturinstitutioner, f.eks. public service-institutionen Danmarks Radio, spiller en væsentlig rolle i sociokulturelle socialiseringsprocesser. De formidler traditionelt både informationer om det samfund og den kultur, de selv er en del af (egen kultur) og informationer om andre samfund og kulturer (fremmede kulturer). Kulturformidlingsinstitutioner opfattes traditionelt som vinduer, som man både kan se indad og udad. Den kultur, der formidles (og som ligeså meget konstrueres af kulturinstitutionerne selv), defineres først og fremmest som den nationale kultur i det omgivne (nationale) samfund, der finansierer disse institutioner. De fremmede kulturer, som kulturinstitutionerne åbner vinduet til (og som de lige så meget er med til at konstruere), defineres som nationale kulturer og fremmede etniciteter, der ligger udenfor det omgivne samfund.

Denne etablerede rolleforståelse for kulturinstitutioner stammer fra en tid, hvor verdenen var overskuelig og nemt kunne deles op i egen kultur og fremmede kulturer. Dette var en verden, hvor det nationalro- 
mantiske ideal om en vidtgående og nærmest naturgiven overensstemmelse mellem en given nations statspolitiske (geografiske), kulturelle og sproglige grænser blev hyldet (Langer, 2003a, s. 22).

Internationaliseringen og globaliseringen - herunder specielt migrationsbevægelserne i den sidste del af det 20. århundrede - resulterede imidlertid i, at kulturinstitutionerne blev mere eller mindre ufrivilligt placeret midt på en politisk slagmark. På denne slagmark betragtede nogle aktører formidlingen af kulturarven som et værn mod globaliseringen. Dette kommenterer Lund (2004, s. 9; se også Ørom, 2004) som følger:

"Kulturarv må ses i sammenhæng med opbrud, ophør og tab af noget velkendt, desto voldsommere brud desto mere fokus på kulturarv. Den angiver et værn mod ikke blot ændringer, men også egentlige opløsningstendenser. Historie og kulturarv mobiliseres som afbigt for oplevelsen af ombrydning af hidtidige fællesskaber og værdimønstre og for at understøtte behov for historisk kontinuitet og identitetsfastholdelse... I kulturarvstænkningen rummes træk af en modernitetskritik og protest, og således udgør den en reaktiv bevægelse...".

Opdelingen mellem egen kultur og fremmede kulturer er blevet udfordret, fordi den monokulturelle nation som kulturformidlingens udgangs- og omdrejningspunktet er blevet afsløret som en tidsbegrænset historisk konstruktion. Derfor er kulturinstitutionernes traditionelle selvforståelse som nationalkulturelle vinduer, som den - i hvert fald som sådan konstruerede - monokulturelle befolkning kunne se indad og udad, blevet problematisk. Kulturinstitutionerne står foran den store opgave at definere, hvis og hvilken kultur de skal formidle. Spørgsmålet er i denne forbindelse, hvad der egen og hvad der fremmed kultur. Lund (2004, s. 15) synes ikke at være i tvivl om dette, idet han kommenterer denne situation som følger:
"I multietniske og flerkulturelle samfund bliver der således andre udfordringer, og snarere end f.eks. 'dansk kulturarv' kunne man tale om 'kulturarv i Danmark"”.

I overensstemmelse med dette har nyere forskning (f.eks. Elbeshausen \& Skov, 2004; Elbeshausen \& Werther, 2004) tematiseret kulturmødeproblematikken i forhold til bibliotekers og andre kulturinstitutioners rolle og funktion i vores samfund.

Interessen for at inddrage etniske minoriteter som emne for den statslige kulturpolitik har været nærmest usynlig indtil midten af 1990'erne (Hvenegaard Rasmussen \& Høyrup, 2000, s. 3). Siden har kulturinstitutioner enten været en slags forlænget arm for skiftende regeringers holdninger til globalisering, migration og omgang med etniske og kulturelle minoriteter eller de har skullet tilbyde kreative rum for diversitet og kulturmøder (Skot-Hansen, 2002a.) Skot-Hansen (ibid.) påpeger begge yderpositioners svagheder ved at afvise det monokulturelle ideal og at anerkende kulturel diversitet - men ved også at påpege faren for, at forestillinger om multikulturisme fasttømrer kulturelle forskelle, reproducerer kulturelle konflikter og øger kulturel relativisme.

Kulturpolitikken er således - ligesom f.eks. social- og arbejdsmarkedspolitikken - blevet en af de centrale kamppladser i den såkaldte danske udlændingedebat. I de senere år er kulturinstitutioner (på delvis egen opfordring) blevet udnævnt som centrale aktører i den såkaldte integration af flygtninge og indvandrere. Integration forstås i denne forbindelse imidlertid oftest som en ensidig tilpasningsproces, hvor institutionerne helt i overensstemmelse med deres traditionelle selvforståelse formidler dansk kultur(arv) til immigranter, der skal lære at indordne sig under diktatet af disse institutioners konstruktion af en monolitisk dansk nationalkultur.

En sådan enhedskulturel kanon udfordres imidlertid ikke kun af migrationsbevægelserne. Den korresponderer samtidig med den - allerede på et tidligere tidspunkt begyndte - erosion af forskellene mellem 
høj og lav kultur. Opløsningen af grænserne mellem lav og høj kultur udfordrer traditionelle kvalitetsbedømmelseskriterier for, hvilke temaer og aspekter af samfundets kulturelle mangfoldighed der bør og skal finde huse i kulturinstitutionernes arbejde. Den øgede kulturelle mangfoldighed skyldes således ikke alene etniske eller nationale forskelle blandt kulturproducenter og -forbrugere, men netop også nedrivningen af mure mellem lav og høj kultur. Begge tendenser bidrager således til at skabe usikkerhed om kulturinstitutioners identitet, mission og legitimitet. Men de skaber samtidig muligheden for, at kulturinstitutioner - herunder biblioteker - skaber nye offentlige rum til den frie debat og meningsudveksling og bliver hybride institutioner (Skot-Hansen, 2002b; Skot-Hansen 2002c).

Denne artikel ønsker at bidrage til debatten om denne udvikling ved at tilbyde en medie- og kommunikationssociologisk forståelsesramme for kulturinstitutionernes rolle i nu- og fremtidens samfund. Denne forståelsesramme peger på, at den enhedskulturelle position og dens politiske applikation som kulturformidling med envejs-tilpasning og kulturel assimilation som mål beror på en forældet kommunikations- og kulturforståelse. I stedet for foreslås en rolleforståelse for kulturinstitutioner som "kulturmødesteder", der anerkender mangfoldigheden i samfundet og netop herigennem muliggør en gensidig kulturtilpasning.

En sådan rolleforståelse er ikke i sig selv ny og blevet argumenteret for tidligere (se f.eks. Rasmussen \& Højrup, 2000; Berger, 2001; Skot-Hansen, 2002d). Men med afsættet i kommunikationsforskningen om netværkskommunikation og social interaktion tilbydes her et kommunikationsteoretisk argumentationsgrundlag og fundament for denne nye rolleforståelse: modsat envejs-formidling af kulturarv, bør kulturmødesteder bidrage til øget social og interkulturel interaktion mellem mennesker med forskellig etnisk, national, social og kulturel baggrund. Udfordringen ligger i en polyfonisk tilgang til kulturinstitutioners kommunikation, dvs. at institutionerne kommunikerer flerstrenget og flerstemmet $\mathrm{i}$ form og indhold som udtryk for accept af den kulturelle mangfoldighed i nutidens samfund - der altså ikke alene vedrører dansk etnicitet, men også forskellen mellem høj og lav kultur.

Efter en introduktion til netværks-metaforen i den sociologiske litteratur, præsenteres kommunikationsforskningen om netværk, efterfulgt af en sektion med særlig henblik på interkulturel kommunikation. Dernæst præsenteres og diskuteres danske erfaringer med netværkskommunikation - både på kulturområdet og på andre områder. Afslutningsvis skitseres kort konsekvenser af netværksperspektivet for kulturmødesteder som biblioteker, museer, arkiver og andre kulturinstitutioner.

\section{Kultur, kommunikation - og integration}

Integration forstået som kulturel envejs-tilpasning fremmet af kulturformidlingsinstitutioner beror på traditionelle propaganda-, kampagne- og kanyleteoretiske forestillinger om, hvordan kultur og samfund kan skabes i og igennem kommunikation. Her forstås kulturinstitutioner som afsendere - eller snarere som medier/kanaler til overførsel af kulturel viden, kulturelle værdier og handlingsmønstre fra en kultur til en anden. Denne opfattelse kan sidestilles med en lineær transmissionsopfattelse for kommunikation. Modsat tager mødested-forståelsen udgangspunkt i et dialogisk kommunikationsperspektiv, der søger at opnå (menings-)fællesskab mellem kommunikatører. Forudsætningen for en sådan dialogisk kommunikationsforståelse er en accept af, at meningsdannelse og interaktion sker på baggrund af allerede eksisterende kommunikationsstrukturer og fælles meninger hos de parter, der søger at interagere med hinanden.

Immigranter ses ud fra propaganda-, massekommunikations- og kanyleteoriens perspektiv oftest som en homogen befolkningsgruppe, der bare skal kommunikeres til med de rigtige budskaber, når det gælder om at opnå nærmere definerede mål. Derved overses, at også immigranter er integrerede i allerede eksisterende sociale og kommunikative netværk, der typisk supplerer den hegemoniske etniske kulturs netværk. 
Disse netværk bør tilkomme stor opmærksomhed, idet:

"[c]ulture ... arises from a network of communications among individuals; and as it emerges, it produces constraints on their actions. In other words, the rules of behaviour that constrain the actions of individuals are produced and continually reinforced by their own network of communications. The social network also produces a shared body of knowledge - including information, ideas and skills, that shapes the culture's distinctive way of life in addition to its values and beliefs. Moreover, the culture's values and beliefs also affect its body of knowledge. They are part of the lens through which we see the world." (Capra, 2004, s. 30).

For at opnå en dybere forståelse af netværk som en grundlæggende betingelse for kulturinstitutioners arbejde, introducerer det efterfølgende afsnit til sociologisk forskning om netværk.

\section{Netværksbegrebet}

Netværksbegrebet er alt andet end et nyt begreb i den samfundsvidenskabelige analyse. Allerede fremtrædende sociologer som Durkheim (1897/1977) og Simmel (1908/1955) havde erkendt og beskrevet betydningen af (kommunikationen i) sociale netværk i forbindelse med skabelsen af individuelle og kollektive identiteter. Med den spansk-amerikanske sociolog Manuel Castells offentliggørelse af et stort trebindsværk om netværkssamfundet (Castells, 1996) fik netværksbegrebet nyt liv i de senere års samfundsvidenskabelige debat. Castells beskriver i dette værk et samfund, hvor nye informations- og kommunikationsteknologier (f.eks. Internettet) skaber fleksible og komplekse netværksstrukturer på lokalt, regionalt, nationalt og globalt niveau. Netværket er iflg. Castells den centrale sociale organiseringsform, der skaber en ny social morfologi i nutidens informationssamfund:
"For the first time, the introduction of new information/communication technologies allows networks to keep their flexibility and adaptability, thus asserting their evolutionary nature. While, at the same time, these technologies allow for co-ordination and management of complexity, in an interactive system which features feedback effects and communication patterns from everywhere to everywhere within the network. It follows and unprecedented combination of flexibility and task implementation, of coordinated decision making, and decentralized execution, which provide a superior social morphology for all human action." (Castells, 1996, s. 470)

Castells' centrale pointe er, at det netop er de nye informations- og kommunikationsteknologier, der gør, at netværk i dag er den dominerende og mest tidssvarende sociale organiseringsform: siden midten af 1970erne oplever vi en kommunikationsrevolution, der har skabt et digitalt mediemiljø. Dette mediemiljø ophæver de analoge massemediers begrænsninger og ophæver distinktionen mellem afsendere og modtagere, idet de giver mulighed for at skabe kontakter, interaktion og alliancer på tværs af tidligere skel i tid og rum. Dette inkluderer et tilsvarende skift i kommunikationsperspektivet "away from broadcast (one to many) towards conversational (many to many) models of communication" (McCarthy, Miller \& Skidmore, 2004, s. 13).

Det er imidlertid ikke så meget selve Castells' beskrivelse af netværkssamfundet og dets digitale grundlag, der er afgørende her (se eksempelvis Qvortrup, 2003 for en nærmere kritisk diskussion). Det er derimod snarere, at Castells' analyse har motiveret mange følgestudier, der ikke kun omhandler den digitale kommunikation (f.eks. Bro, 2003; Hansen, 2003; Sampson, 2004; Hargreaves, 2004; Stephenson, 2004), som satte fornyet fokus på social interaktion i forskellige typer netværk. Og selvom Castells måske overvurderer medieteknologiernes betydning, kan der ikke være nogen tvivl om, at digitaliseringen og den stigende udbredelse af interaktive medier har rystet den traditionelle kommunikationsforskning, 
hvor massemediekommunikationen over årtier havde været det, der dominerede forskningen (Langer, 2004).

\section{Social interaktion i kommunikationsnetværk}

Netværk har dog i dele af kommunikationsvidenskaben (ligesom i antropologien, sociologien og psykologien) haft stor betydning (jf. Yum, 1989, s. 486). Katz og Lazarsfeld - to af kommunikationsdisciplinens grundlæggere - erkendte allerede $\mathrm{i}$ midten af det 20 . århundrede, at borgernes forbrugsmønstre var mindre styrede af massemediernes politiske propaganda og reklamer end af deres nære personlige omgivelser (Katz \& Lazarsfeld, 1944; 1955). Dette resulterede i deres skelsættende model om "two step flow communication", der kombinerede massemedial og interpersonel påvirkning qua meningsdannere i sociale netværk:

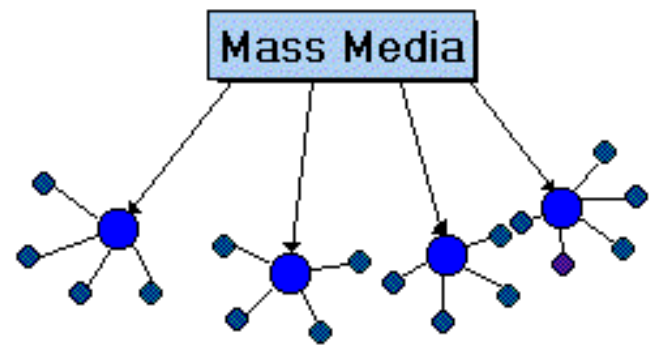

= Opinion leaders

$\sigma=$ individuals in social contact with opinion leaders

Figur 1: Two step flow-model. Illustration fra: http:// www.cultsock.ndirect.co.uk

Tilsvarende nåede den amerikanske socialpsykolog Samuel A. Stouffer (Stouffer et al, 1949) i sine studier om krigspropaganda til den erkendelse, at soldaters kampmoral var mindre styrede af hærledelsens propaganda end af deres tætte relationer til andre soldater.

Sociale netværk består af sekventielle kommunikationsmønstre:
"I netværk vil kommunikationen ... typisk foregå mellem to eller få deltagere i netværket og den vil brede sig til andre som en kædereaktion, hvor det enkelte individ kan have (eller tiltage sig) større eller mindre indflydelse på både indhold (hvad) og videre udbredelse (til hvem). Netværkets funktion beror på det enkelte individs direkte medvirken i kommunikationen" (Finnemann 2003, s. 43).

Alle mennesker er medlemmer af forskellige mere eller mindre formelle netværk, der også kan karakteriseres som "communities of practice", dvs. fællesskaber (grupper og organisationer) der konstituerer sig om og qua kommunikative praksisser. Kommunikationsnetværk består således af "interconnected individuals who are linked by patterned communication flows" (Rogers, 1986), der skaber menneskers strukturelle organisering i og tilhørsforhold til grupper og andre kollektive enheder:

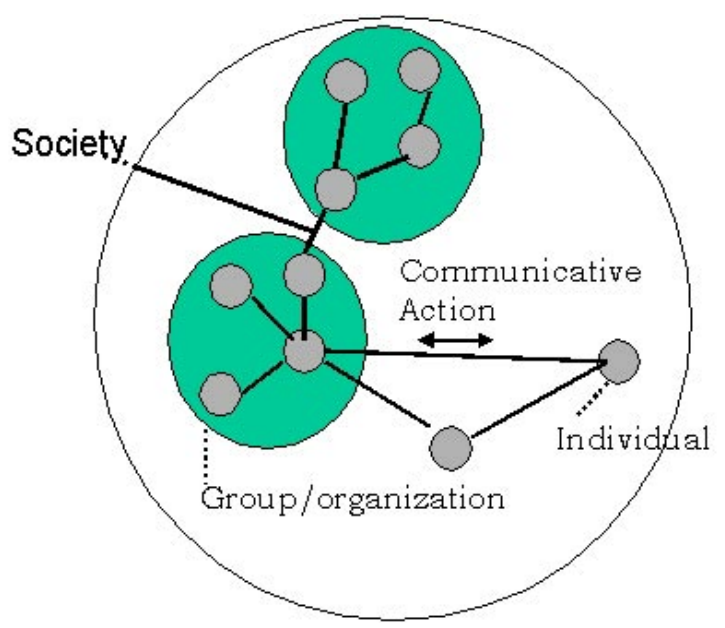

Figur 2: Netvaerk, der forbinder individer, gruppelorganisationer og samfund qua kommunikative handlinger

Kilde: Van Dijk (2001)

Der skelnes grundlæggende mellem simple og komplekse netværk. De fleste netværk er simple netværk, der er integrerede dele af allerede eksisterende systemiske netværk, f.eks. fagforeninger, organisationer og institutioner. Simple netværk har en struktur, hvor 
medlemmerne har parallelle relationer til et samlende centrum - uden at netværkets medlemmer nødvendigvis er relaterede til og direkte kommunikerer med hinanden. Her er det de formelle strukturer og hierarkier, der er afgørende for netværkets opbygning. $\mathrm{Ud}$ fra et kommunikationsperspektiv er det imidlertid mere interessant at se på komplekse netværk, der er uafhængige af disse formelle systemstrukturer og hvor medlemmerne engagerer sig på frivillig basis. Komplekse netværk er eksempelvis familier, hjælpeorganisationer, Internet-fællesskaber etc. Disse netværk er mindre baserede på formelle strukturer end på fælles interesser blandt deres medlemmer, der også søger og indgår interpersonelle relationer med hinanden.

Simple netværk er mest efficiente, når det gælder udførelsen af rutineopgaver. Komplekse netværk er derimod mere velegnede og efficiente, når kreative problemløsninger forudsætter interaktion og samarbejde mellem netværkets medlemmer. Medlemmerne er mere tilfredse, når det gælder om at løse opgaver og problemer i komplekse organisationer end i simple organisationer (Monge \& Contractor, 2001, s. 447). Dette er særlig relevant, når det gælder om at iværksætte innovationer (som f.eks. kulturelle møder og overvindelse af kulturel adskilthed), således at kulturmøder først og fremmest bør finde sted som et tilbud, som deltagerne selv har mulighed for at præge og udvikle.

Udover forskellen mellem simple og komplekse netværk skelner Perri (2004, s. 133-134) med afsæt i antropologen Mary Douglas' og sociologen Emile Durkheim's arbejde mellem hhv. enklaver, individualistiske, hierarkiske og isolerede netværk:

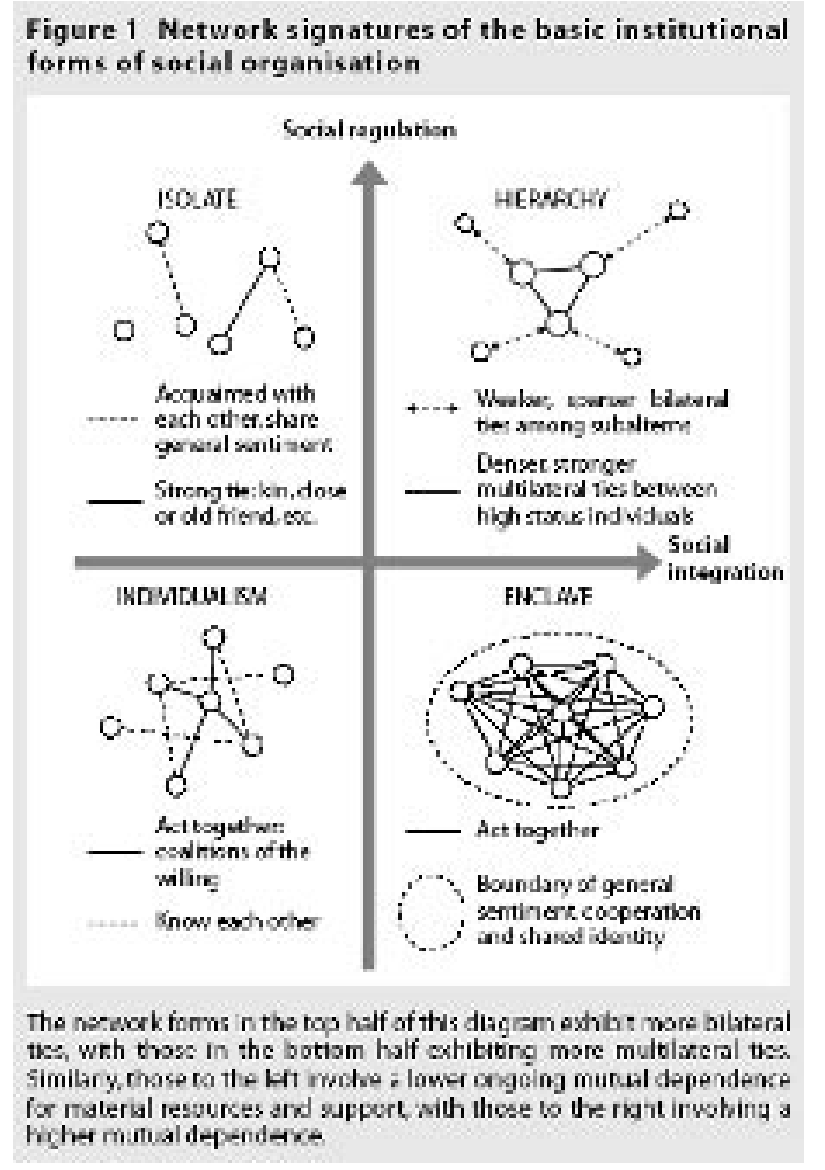

Figur 3: Grundtyper af netvaerk (Perri, 2004, s. 135)

Disse fire grundtyper af netværk adskiller sig fra hinanden med henblik på graden af social regulering og social integration - hvor grænserne mellem de enkelte grundtyper imidlertid er flydende. Individualistiske netværk er forholdsvis åbne netværk, der muliggør kontakt til personer, der er anderledes end én selv. Disse netværk kan bruges instrumentelt over kortere eller længere perioder til eksempelvis professionelt "networking"-arbejde og har en lav grad af både social regulering og social integration. Enklaver har ligeledes en lav grad af social regulering, men kendetegnes af en større grad af social integration. Denne netværkstype er i større grad karakteristisk for forholdsvis lukkede praksisfællesskaber, som eksempelvis etniske minoritetsfællesskaber. Hierarkiske netværk karakteriseres af en høj grad 
af social regulering og social integration. Disse netværk har oftest en central inderkreds med stor magt og træder i praksis frem som eksempelvis loger eller religiøse fællesskaber. Sidstnævnte karakteriseres typisk af en i høj grad formel envejs-kommunikation. Dette betyder, at succesfuld kommunikation med hierarkiske netværk forudsætter en tæt kontakt med deres magtfulde inderkreds og at denne inderkreds bør involveres i kommunikationsopgaven. Oftest er en sådan kontakt kun mulig ved at synliggøre incitamenter og fordele for denne specifikke inderkreds. Endelig findes der isolerede netværk, der har en høj grad af social integration og en lav grad af social regulering. Kontakten mellem netværkets medlemmer er her ikke nødvendigvis regelmæssig, sådan som det eksempelvis er tilfældet i mange etniske danskeres familiære netværk.

Netværkets karakter bestemmes imidlertid ikke kun af medlemmerne indefra, men også af omgivelserne og medlemmernes behov i forhold til omgivelserne. Når det gælder etniske minoritetsnetværk vil mange af disse netværk være styrede af konstruktionen af det indre fællesskab med afsæt i fælles etnicitet, kulturel baggrund eller religion. Men også immigranters muligheder for og interesse $i$ at blive del af traditionelle danske netværk spiller en rolle her. Hvis mulighederne eller interessen mangler, vil minoriteter afgrænse sig fra den omgivne hegemoniske kultur og have karakter af enklaver og/eller hierarkiske netværk.

Det interessante ud fra et ønske om kulturmøder er i denne forbindelse, at minoritetsnetværk oftest ikke kan nås qua majoritetskulturens etablerede mediekanaler og kommunikationsstrategier. Dette bliver eksempelvis synligt ved alle de parabol-antenner, som mange etniske minoritetshusholdninger har installeret og som modtager tv-kanaler på oprindelseskulturens sprog og/eller fra herkomstlande. Massemediet tv, der fortsat kan forene store dele af den etnisk danske befolkning (et nyere eksempel er DR's underholdningssucces "Nikolaj og Julie"), er således ikke en særlig velegnet kommunikationskanal, såfremt man ønsker at skabe kulturmøder.
Det er imidlertid ikke tilstrækkeligt kun at typeidentificere graden af social regulering og integration i netværk, såfremt kommunikationsplanlægningen skal lykkes. Et ligeså vigtigt element i planlægningsarbejdet er selve netværksanalysen. Modsat identifikation af netværkets formelle organisation og struktur viser netværksanalysen, hvor og hos hvem medlemmerne opsøger viden og informationer, og hvem de deler denne viden og disse informationer med. Netværksanalysen har således til formål at undersøge, hvordan netværksrelationerne påvirker individers viden, holdninger og handlinger. Muligheden for påvirkning afhænger bl.a. af det analyserede netværks egenskaber, der omfatter dets grad af åbenhed, integration, diversitet og styrken af de interne kohæsionskræfter (se også Monge \& Contractor, 2001 for yderligere karakteristika). At disse parametre er afgørende for kommunikationens succes påviste bl.a. Rogers \& Kincaid (1981) i et klassiske studie om, hvordan kvinderne i en lille koreansk landsby søgte at forbedre deres og deres families livsbetingelser med afsæt i netværkskommunikation.

Netværksanalysen kan foretages ved hjælp af spørgeskemaundersøgelser, personlige interviews eller observationsmetoder. Afhængig af typen af de anvendte data anvendes statistiske softwareprogrammer, interview- og observationsanalyseteknikker med henblik på at kortlægge antal, styrke og omfang af sociale netværksrelationer, samt med henblik på at identificere knudepunkter (dvs. nøglepersoner og meningsdannere) i sociale netværk. Der findes en række skoledannelser indenfor netværksanalysen, der arbejder ud fra en hhv. positionel, relationel eller kulturel tradition samt ud fra et hhv. byttehandels-, ressource-, konvergens-ellerkognitionsperspektiv(m.fl.). Tilsvarende beror analysen af kommunikationsnetværk på en række forskellige metodiske tilgange, som f.eks. sociogrammer, sociomatrix-, faktor- og cluster-analysen (se Wigand, 1988, for et overblik).

Netværkskommunikationsforskningen er således alt andet et homogent paradigme eller en konsensusbaseret retning eller skole i kommunikationsforskningen. Eftersom det dog ikke er denne artikels overord- 
nede formål at udrede metodediskussioner, fokuserer den efterfølgende sektion på den interkulturelle netværkskommunikationsforsknings empiriske indsigter.

\section{Interkulturel netværkskommunikation}

Interkulturel kommunikation er en interaktionsproces mellem mennesker og/eller organisationer med forskellig kulturel eller etnisk oprindelse. Interkulturel netværkskommunikationsforskning sætter fokus på den konkrete kommunikative handlings forankring i kommunikatørernes socio-kulturelle baggrund og kontekst (Yum, 1989, s. 487). Det handler m.a.o. ikke om at forstå kommunikation som en opdeling mellem afsender, budskab, medie, kanal og modtager, som en overførsel af information - men derimod om at forstå kommunikatører som integrerede dele i allerede eksisterende netværk.

Interkulturel kommunikationsforskning om netværk kan overordnet inddeles i fem hovedområder: kulturel diversitet, diffusion af innovationer, migration fra by til land, etnicitet og kulturel tilpasning af immigranter (Yum, 1984). I forbindelse med danske kulturinstitutioners rolleforståelse i forhold til etniske minoriteter i Danmark, er det specielt forskningen i det sidstnævnte område, der er af relevans. Allerede i 1920erne og 1930erne udførte medlemmer af "The Chicago School of Sociologists" første immigrationsstudier, der dokumenterede, at kulturel tilpasning er en langvarig proces og at etniske og kulturelle minoritetsnetværk ikke bør bekæmpes ud fra en antagelse om, at de står i vejen for kulturel tilpasning. Tværtimod viste medlemskabet $\mathrm{i}$ denne type netværk sig snarere at være en ressource, der kunne understøtte og at fremme kulturel tilpasning.

Den hidtil frembragte forskning viser også, at enklaver og isolerede minoritetsnetværk typisk ikke selv kan tilbyde medlemmerne et tilstrækkeligt informationsgrundlag med henblik på at fremme deres kulturelle tilpasning. Det er således de netværk, hvor de formelle relationer er svagest, der også er mest åbne for information og kommunikation med den omgiv- ne verden, og som har størst mulighed for kulturel tilpasning (Yum, 1989). Det bør dog understreges, at etniske minoriteter ofte opfatter majoritetskulturens kulturinstitutioner som del af et allerede veletableret systemnetværk. Her er det alene graden af åbenhed i og fra disse systemnetværk, der vil være afgørende for, hvorvidt interkulturel kontakt er mulig. Netop sidstnævnte er tilsyneladende blevet erkendt af en række danske offentlige institutioner, hvilket den efterfølgende kritiske diskussion af første netværkskommunikationserfaringer synliggør.

\section{Eksempler og erfaringer med netværkskommu- nikation i Danmark}

I Danmark foreligger der en række erfaringer med netværkskommunikation fra forskellige offentlige institutioners kampagner, f.eks. fra trafik-, el-spare- og ernæringsvejledende kampagner, samt fra kulturinstitutioners arbejde og fra Sundhedsstyrelsens forebyggende sundhedsarbejde.

Tidligere beroede eksempelvis det sundhedsforebyggende arbejde typisk på en mediestrategi, der omfattede massemedierede informationskampagner til store grupper af modtagere. I 1990erne voksede erkendelsen af, at disse oplysningskampagners effekter ikke var tilfredsstillende. Derfor begyndte man fra myndighedernes side i stigende grad at arbejde med en netværksstrategi, der i nogle tilfælde fungerede som et supplement og $i$ andre som et alternativ til traditionelle massemediekampagner. Mens eksempelvis HIV- og AIDS-kampagner indtil midten af 1990erne primært beroede på massemedieannoncer og -film, der henvendte sig til den brede befolkning, har indsatsen i de senere år været mere selektiv og målrettet mod sociale netværk i de identificerede særlige risikogrupper. Netværkskommunikationen var et oplagt udgangspunkt, også fordi det var vanskeligt at etablere dialog med disse risikogrupper qua massemedierne. Således søgte Sundhedsstyrelsen at involvere allerede etablerede netværk blandt f.eks. eksportchauffører, homoseksuelle mænd og prostituerede i sit oplysende, holdningsprægende og handlingspåvirkende arbejde. 
Også i den kommercielle kommunikation og markedsføring har netværkskommunikationen fået stor betydning. Som nogle af de første brancher opdagede tobaks- og medicinalindustrien værdien af netværk for deres kommunikation, fordi disse brancher grundet lovmæssige restriktioner ikke kunne kommunikere direkte med slutbrugerne/forbrugerne. I stedet for anvendte de andre markedsføringsteknikker, som f.eks. relationsmarkedsføring og virus-markedsføring. Dette er kommunikationsstrategier, der søger at påvirke forbrugernes viden, holdninger og handlinger med afsæt $\mathrm{i}$ interpersonel netværkskommunikation.

Fælles for disse praktiske eksempler for netværkskommunikationen er en forventning om, at den personlige, nære og relevante formidling af information i sociale netværk skaber større troværdighed for budskabet. Strategien anvendes netop, når emnet er "svært" og ikke interesserer målgruppen. Men erfaringerne viser også, at muligheden for anvendelse af netværkskommunikationen afhænger af den konkrete målgruppe og dens sociale kontakter. Tilmed må man være indstillet på, at man som initiativtager til og afsender i kommunikationen ikke har den fulde kontrol over kommunikationsprocessen. Således kan budskabet blive modificeret og ændret under spredningsforløbet $\mathrm{i}$ et givent netværk. Endelig påpeger erfaringerne fra Sundhedsstyrelsens arbejde muligheden for nedslidning af netværket, dvs. at ofte anvendte samarbejdspartnere oplever en langsigtet belastning og et kapacitetsproblem, der i længden kan svække netværkskommunikationen, såfremt disse partnere bliver anvendt for ofte og for meget. Sundhedsstyrelsen (2002) sammenfatter sine erfaringer med netværkskommunikation på følgende måde:

"Netværksstrategier er ikke egnede til

1. kampagner med kort planlægningstid

2. kampagner af kort varighed

3. kampagner rettet til hele befolkningen og til store heterogene målgrupper

4. kampagner hvor der ikke eksisterer et fundament af kendskab til problemet i målgruppen

5. kampagner med mange mål og målgrupper
6. situationer hvor der ikke er tid og ressourcer til grundig planlægning, forundersøgelser og løbende formative evalueringer.

og netværksstrategier skal overvejes ekstra grundigt

7. når målgrupperne er geografisk spredte

8. når målgrupperne har ringe indbyrdes kontakt

9. når målgrupperne har få eller ingen fælles eller ensartede netværk

10. når målgrupperne ikke har ensartede personlige kontakter

11. når målgrupperne ikke har fælles eller ensartede sluser

12. hvis kampagnen medfører stor afhængighed af interesser uden for senderens organisation

13. i situationer hvor det ikke er muligt at arbejde med fleksibel budgettering og planlægning."

Andre vigtige erfaringer med netværkskommunikation er, at man bør være opmærksom på at skelne mellem netværksmålgrupper og slutmålgrupper. Dette betyder, at networking-arbejdet med relevante opinionsdannere i sociale netværk ikke er målet i sig selv, idet disse opinionsdannere kun er "værktøjer", der skal overbevise slutmålgruppen. Det er således ikke tilstrækkelig at se på, om samarbejdet med disse partnere og opinionsdannere i sociale netværk fungerer. Vigtigere er i sidste ende, at disse opinionsdannere formår at sprede budskaber i deres respektive netværk.

Der foreligger også første erfaringer med netværkskommunikation hos danske kulturinstitutioner. Forskningsministeriets rapport "Information til tiden" (1997) om den offentlige informationspolitik anbefalede nemlig blandt andet, at offentlige institutioner skulle kommunikere på minoritetssprog, benytte sig af lokale minoritetsmedier og -netværk, samt tage udgangspunkt i borgernes behov. Siden blev der iværksat en række initiativer, såsom brugen af konsulenter for biblioteksbetjening af etniske minoriteter på Biblioteksstyrelsens indsatsområde "Det globale i det lokale". Disse konsulenter udviklede 
strategier, der netop skulle tilgodese etniske minoriteters videns-, kultur- og informationsbehov. Det afgørende var i denne forbindelse, at biblioteker her netop ikke var ensidige kulturformidlingsinstitutioner, men derimod fungerede som tværkulturelle mødesteder, hvor der i samarbejde med f.eks. Dansk Flygtningehjælps frivilliggrupper blev organiseret aktiviteter, der fokuserede på og tog højde for den etniske og kulturelle mangfoldighed i dagens Danmark. Tilsvarende har nyere forskning i kulturinstitutioners rolle $\mathrm{i}$ et multikulturelt samfund påpeget, at hverken oversocialisering eller formidling af viden synes at være nøglen til at danne bro over kulturelle kløfter; og at "integration" - forstået som en længerevarende og tidskrævende kommunikations- og interaktionsproces beroende på gensidig tilpasning. Denne proces forekommer således mest sandsynlig at lykkes, når etniske minoritetsnetværk involveres $i$ et arbejde ved at skabe så mange kontakt- og interaktionspunkter til netværk som mulig (Elbeshausen \& Skov, 2004).

Biblioteksstyrelsens nyeste kampagne "Biblioteket - porten til det danske samfund" fortjener i denne forbindelse særlig opmærksomhed. Titlen synes umiddelbart at indikere, at det netop handler om at kulturinstitutioner åbner deres vindue til det danske samfund, uden også at være en port til de etniske minoriteters kultur. Titlen kan derfor nemt forstås som en reaktivering af ønsket om kulturel envejs-tilpasning, der imødegår kulturel mangfoldighed - og kunne tyde på den indledningsvis formulerede forestilling om, at kulturinstitutioner fungerer som skiftende regeringers forlængede arm. Således skal kampagnen "Biblioteket - porten til det danske samfund" ifølge den nuværende danske regerings målformulering sikre en mere offensiv formidling af bibliotekernes læringstilbud om det danske samfund.

Ser man imidlertid på de eksempler, som KraghSchwarz \& Poulsen (2004) har samlet og udgivet med henblik på at inspirere til konkrete projekter i kampagnen, viser sig en større mangfoldighed. Der er naturligvis projekter, som sigter mod at formidle etniske minoriteter viden og færdigheder, der er nød- vendige for at kunne begå sig på det danske arbejdsmarked (f.eks. Weisbjerg \& Elbeshausen, 2004, s. 7) eller i det danske uddannelsessystem (f.eks. Fangel, 2004, s. 5). Men der er også andre projekter, som f.eks. et Afrikafestival og debatmøder i Skive (Seidenfaden, 2004, s. 4), et debatteater i Gellerup (Vedel Larsen, 2004, s. 30) eller et aktivitetsrum for unge piger i Vollsmose bibliotek (Poulsen, 2004, s. 33), hvor biblioteker fungerer som offentlige rum, hvor kulturen formidles begge veje og kan resultere i læring hos både kulturelle minoritets- og majoritetsmedlemmer.

Fælles for alle disse eksempler er, at biblioteker $\mathrm{i}$ kraft af deres lokale forankring søger interaktionen med de etablerede minoritetsnetværk. Her har biblioteker indlysende fordele sammenlignet med andre kulturinstitutioner, som f.eks. operahuse, arkiver eller mange museer. Fordele, som biblioteker også allerede forstår at benytte sig af. Det er netop kontakten til minoritetsnetværkene og muligheden for at åbne det lokale bibliotek ikke bare som et kulturformidlings- men også som et kulturmødested, der anerkender kulturel mangfoldighed og etnicitet, der ligger til grund for bibliotekernes succesfulde arbejde. Og som - måske som paradoks - omvendt motiverer det tidligere omtalte initiativ til en mere offensiv formidling af bibliotekernes læringstilbud om det danske samfund.

De foreliggende erfaringer med netværkskommunikation dokumenterer, at der i stigende grad anvendes modtagerorienterede og netværksbaserede "pull"strategier, frem for senderorienterede og massemediebaserede "push"-strategier. "Push"-strategier sigter typisk mod informationsformidling med afsæt $i$ afsenderens interesse og styringsbehov, når de søger at overtale målgruppen til at ændre viden, holdninger og handlinger. Derimod tager "pull"-strategier typisk udgangspunkt i eksisterende sociale netværk i de befolkningsgrupper, man ønsker at komme i kontakt med. I stedet for overtalelse handler det her snarere om etablering af kommunikationstilbud, der søger at involvere disse mennesker i et samarbejde baseret på partnerskab og frivillighed. 
De konkrete tiltag til og erfaringer med netværkskommunikation viser imidlertid også, at denne strategi ikke altid og per definition er en modtagerorienteret kommunikationsstrategi. En del af initiativerne på området synes derimod i sidste ende at arbejde ud fra en diffusionstankegang, hvor netværket bruges som et værktøj eller en kommunikationskanal med henblik på at sikre, at afsenderens budskab "rammer" målgruppen. Der er således tale om ensidige påvirkningsforsøg, hvorfor det ville være rigtigere at betegne dette perspektiv som netværksdiffusion $\mathrm{i}$ stedet for netværkskommunikation. Netværksdiffusionen er dermed i sidste ende en modificeret udgave af en lineær transmissionsforståelse af kommunikation og af en push-strategi, der tilmed typisk tager afsæt $\mathrm{i}$ den simple netværkstype, hvor den lineære kommunikation er dominerende. Konsekvenserne af en sådan netværkstilgang forekommer åbenlyse: ved netværksdiffusionen ville der, når det bliver anvendt strategisk på kulturområdet, i sidste ende stadig være tale om et ønske om ensidig kulturel tilpasning (»one-way acculteration«).

Det bør i denne forbindelse understreges, at den her rejste kritik alene gælder det bagvedliggende perspektiv og den bagvedliggende kommunikationsforståelse. Den vedrører således ikke diffusionsforskningens analyseresultater om gradvis tilegnelse af innovationer i diverse populationer (se Rogers, 1995). Men, "[f]rom a knowledge management perspective ... [w] now understand better than ever that innovation is very often a social interactive process rather than one of individual creativity, and that networks play a vital role in the creation and the transfer of new knowledge and innovation." (Hargreaves, 2004, s. 85)

Ved siden af denne opfattelse af netværkskommunikation eksisterer der et andet perspektiv på netværkskommunikation, der sigter mod gensidig meningsskabelse og fællesskab qua dialog. Her vil der - modsat netværksdiffusionen - være tale om en gensidig og reciprok kulturel udveksling og tilpasning (»reciprocal acculteration«). Ud fra dette perspektiv er der ikke tale om en kommunikation fra afsender til modtager, men mellem flere kommunikatører i et fælles og komplekst netværk, hvor kommunikatørerne er både afsendere og modtagere, og hvor kommunikationen foregår på kryds og tværs. Den afgørende forskel i forhold til diffusionsstrategien er, at der i tilrettelæggelsen af kommunikationen ikke udelukkende tages udgangspunkt i spørgsmålet "Hvilken viden skal vi formidle, hvilke holdninger og handlinger hos netværkets medlemmer søger vi at påvirke?" - men at udgangspunktet i mindst lige så høj grad er spørgsmålet "Hvad er det, vi kan tilbyde netværkets medlemmer, der er af relevans og interesse for dem? Og - ikke mindst - hvad kan netværkets medlemmer tilbyde, der kunne være af interesse og relevans for os?"

\section{Konklusion}

Denne artikel har argumenteret for at anskue kommunikation ud fra et dialogisk kommunikationsperspektiv, der sætter fokus på social organisering og interaktion i kommunikationsnetværk. Ud fra et sådant perspektiv er en rolleforståelse for kulturinstitutioner som formidlere af dansk ikke længere tidssvarende, idet den afspejler en kommunikationsforståelse, som kommunikationsforskningen både teoretisk og empirisk har modbevist. Resultaterne af denne forskning kan således fungere som forståelsesramme for og støtte til rolleforståelse af kulturinstitutioner som kulturmødesteder, der formidler kultur i Danmark. Modsat kulturformidlingskonceptet, forstås medlemmer af etniske minoriteter her snarere som partnere i kommunikationen end som modtagere af information. En sådan kommunikations- og rolleforståelse er ikke mindst forudsætning for, at kulturinstitutioner kan etablere den nødvendige kontakt til og opnå den nødvendige støtte for deres arbejde hos opinionsledere i de etniske og kulturelle minoriteters sociale netværk, der således kan fungere som forandringsagenter, der motiverer og engagerer etniske minoriteter til aktiv deltagelse $\mathrm{i}$ kulturmøder og samfundet som helhed.

Der foreligger - specielt i bibliotekernes arbejde - en række eksempler på, at en sådan teoretisk og empi- 
risk motiveret forståelse af kulturformidlingsinstitutionernes rolle også øger minoriteters engagement og muligheder i det danske samfund. Alligevel overses ofte, at der også findes en anden rekrutteringsmulighed for forandringsagenter i etniske netværk. En målrettet uddannelsesindsats og ansættelsesstrategi på kulturinstitutioners område ville i denne forbindelse på længere sigt kunne skabe endnu bedre kontakt til de etniske minoriteters netværk. Rekrutteringsspørgsmålet er imidlertid ikke det eneste aspekt, der bør tages i betragtning. Ingemann Larsen, Jacobs \& van Vlimmeren (2004) peger i deres rapport "Cultural diversity. How libraries can serve the diversity in the community" og med henvisning til en række internationale "best practice"-eksempler (herunder fra Indvandrerbiblioteket, Århus, Odense og Greve) på en række andre indsatsområder, når det gælder om at definere, hvordan biblioteker og andre kulturinstitutioner kan imødekomme den stigende kulturelle diversitet i samfundet. Disse indsatsområder omfatter udover netværkskommunikation, der har været i fokus i denne artikel, og udover det nævnte rekrutteringsspørgsmål: målgruppestudier og forbrugerforskning, organisations- og ledelsesmæssige udfordringer, brug af alternative finansieringsmodeller til institutionernes virksomhed og marketing m.fl.

Den her foreslåede rolleforståelse er ikke udtryk for et - måske blåøjet - ønske om et utopisk herredømmefrit fællesskab mellem kulturinstitutioner og etniske eller andre minoritetsgrupper i et fragmenteret samfund. Der er snarere tale om en pragmatisk tilgang, der anerkender og servicerer den etniske og kulturelle mangfoldighed i dagens samfund - og ikke søger ensretning og uniformitet. Det pragmatiske vedrører offentligt finansierede institutioners fremtidige legitimitet og mulighed for at overleve (Langer, 2002; Hansen, Langer \& Salskov-Iversen, 2004). At kunne både $\mathrm{i}$ form og indhold imødekomme befolkningens heterogenitet på dens egne præmisser er naturligvis en stor udfordring - men den forekommer netop som et hensigtsmæssigt svar på samfundets tiltagende komplekse heterogenitet. Lignende krav stilles til virksomheder, der i stigende grad bliver nødt til at kommunikere polyfonisk ved også at udvise so- cialt ansvar, miljøansvar osv. eller til forskere, der ikke bare skal forske, men også formidle deres forskning. Dette forudsætter bogstaveligt talt læring af nye sprog: virksomheder må lære at kommunikere om andet end økonomi og penge, forskerne må aflære sig fremmedord - og kulturinstitutioner må lære at forholde sig til mangfoldigheden af etniske, mediale og kulturelle former og indhold.

Nationalstatens erosion, statens tab af autoritet og den øgede markedsgørelse af hele samfundet rejser spørgsmålet, hvad der i fremtiden holder samfundet sammen. Ligesom erhvervslivet må offentlige (kultur)institutioner i denne forbindelse tage et ansvar og skabe nye muligheder for at sikre interaktion og relationer mellem borgerne: "The idea of the well-connected community should not be seen as a nostalgic, communitarian model of urban neighbourhoods or village life. It is a radical approach that celebrates the dynamic and multi-faceted nature of our lives while asserting the value of social connectivity. Community development strategies that strengthen and extend informal networks are essential to tackling social exclusion and building community cohesion. They improve and sustain partnership working by building trust between partners and ensuring representative community involvement. These processes are not amenable to the current audit regimes of targets and indicators, and progress is better measured using techniques of participatory appraisal and network analysis" (Gilchrist, 2004, s. 153-154).

Formidlingen af en enhedskulturel kanon tilhører fortiden. Organiseringen af social interaktion og interkulturel kommunikation mellem netværk er én af de opgaver, kulturinstitutionerne kan og bør varetage i stedet for - ikke mindst for at legitimere deres egen eksistens. At kunne navigere mellem politiske krampetrækninger, der søger at bevare fortiden, og at kunne legitimere deres egen eksistens i fremtiden, er i denne forbindelse kulturinstitutionernes største aktuelle udfordring. 


\section{Taksigelse}

Forfatteren takker hermed sine to anonyme reviewere for deres tankevækkende og konstruktive kommentarer, samt tidsskriftets redaktører for deres tålmodighed under artikelrevisionen. Udarbejdelsen af artiklens teoretiske del er blevet til med støtte af Statens Samfundsvidenskabelige forskningsråd til projektet PRO-MEDIA.

\section{Litteratur}

Barabási, A-L (2002). Linked. The New Science of Networks. Cambridge (MA) : Perseus Publishing.

Berger, Å (2001). Mangfoldighedens biblioteker: flersproglig biblioteksbetjening i Danmark. København : Bibliotekarforbundet.

Bro, P (2003). Netværk i nyhedsmedierne - et forskningsprojekt fra 2002-2004, i Bondebjerg, I \& Bank, H. Modinet-Temanummer Netvarksbegrebet og Netvaerkssamfundet. Working Paper No. 4, København : Modinet, 83-89.

Capra, F (2004). Living Networks, i: McCarthy, H; Miller, P \& Skidmore, P (eds'). Network Logic. What governs in an interconnected world? London : Demos, 25-34.

Castells, M (1996). The Rise of the Network Society. Oxford : Blackwell Publishers.

Castells, M (2001). The Internet Galaxy. Reflections on the Internet, Business, and Society. Oxford : Oxford University Press.

Castells, M (2003). Netvaerkssamfundet og dets opståen. København : Hans Reitzels Forlag.

Castells, M (2004). Afterword: why networks matter, i: McCarthy, H; Miller, P \& Skidmore, P (eds'). Network Logic. What governs in an interconnected world? London : Demos, 221-225.
Durkheim, É (1897/1977). Suicide: A study in sociology. New York: The Free Press (oprindelig udgivet i 1897).

Elbeshausen, H \& Skov, P (2004). Public libraries in a multicultural space - a case study of integration processes in local communities. New Library World, 105 (1198/1199), 131-141.

Elbeshausen, H \& Werther, C (2004). The Intercultural Encounter between Public Danish Libraries and Ethnic Minority Users, i: Johannsen, C. G. \& Kajberg, L. (eds.), New Frontiers in Public Library Research. Lanham, Maryland and London : The Scarecrow Press Inc. (under udgivelse).

Fangel, G (2004). Børn og unge I Danmark - studiekreds for somaliske forældre med børn i skolealderen, i: Kragh-Schwarz, B \& Poulsen AK. Biblioteket - en port til det danske samfund. Eksempler til inspiration. København : Biblioteksstyrelsen, 5-6.

Finnemann, NO (2003). Netværk, medier og identitet, i: Bondebjerg, I \& Bank, H. Modinet-Temanummer Netvarksbegrebet og Netvarkssamfundet. Working Paper.

Forskningsministeriet (1997): Information til tiden. Betoenkning fra Udvalget om Offentlig Informationspolitik. København: Forskningsministeriet.

Gilchrist, A (2004): Developing the well-connected community, i: McCarthy, H; Miller, P \& Skidmore, $\mathrm{P}$ (eds'). Network Logic. What governs in an interconnected world? London : Demos, 145-154.

Hansen, HK (2003). Knowledge Society Newspeak Dissemination and Advanced Liberalism: Governing through Digitalized Transnational Partnerships, i Bondebjerg, I \& Bank, H. Modinet-Temanummer Netvarksbegrebet og Netvarkssamfundet. Working Paper No. 4, København : Modinet, 54-82.

Hansen, HK; Langer R \& Salskov-Iversen, D (2004). "Politisk Kommunikationsledelse i Horsens", i: Pe- 
dersen, D (red.): Ny ledelse i det offentlige. Frederiksberg: Samfundslitteratur. (in press)

Hargreaves, DH (2004). Networks, knowledge, and innovation, i: McCarthy, H; Miller, P \& Skidmore, P (eds'). Network Logic. What governs in an interconnected world? London : Demos, 79-88.

Hvenegaard Rasmussen, C \& Høyrup, CL (2000). Kulturinstitutioners bidrag til det kulturelt mangfoldige Danmark - en undersøgelse af kunst-og kulturformidlingsinstitutioners tilbud til og inddragelse af de etniske minoriteter. København : Center for Kulturpolitiske Studier, Danmarks Biblioteksskole.

Ingemann Larsen, J; Jacobs, DL \& van Vlimmeren, $\mathrm{T}$ (2004). Cultural diversity. How libraries can serve the diversity in the community. Gütersloh : Bertelsmann Stiftung.

Katz, E \& Lazarsfeld, PF (1944). The People's Choice. New York : Columbia University Press.

Katz, E \& Lazarsfeld, PF (1955). Personal Influence. New York: The Free Press.

Kragh-Schwarz, B \& Poulsen AK (2004). Biblioteket - en port til det danske samfund. Eksempler til inspiration. København : Biblioteksstyrelsen.

Langer, R (2002). Place Images and Place Marketing, i: Helder, J \& Kragh, SU (red.): Senders and Receivers. Frederiksberg : Samfundslitteratur, s. 59-96.

Langer, R (2003a). Zur Darstellung Deutschlands in dänischen Medien. Wiesbaden: Deutscher Universitätsverlag.

Langer, R (2003b). Social Interaction in and between Communication Networks, Nordic Conference "Multicultural Competences - Shared Challenges", Oslo, 24.11.2003.

Langer, R (2004). Hvad er Kommunikationsvidenskab? Status og fremtid for en udisciplineret disci- plin. Dansk Kommunikationstidsskrift, Nr. 1 (under udgivelse).

Lund, ND (2004). Kulturarv - et begreb mellem politik og information. Biblioteksarbejde nr. 67/68, 7 27.

McCarthy, H; Miller, P \& Skidmore, P (2004). Introduction, i: McCarthy, H; Miller, P \& Skidmore, P (eds'). Network Logic. What governs in an interconnected world? London : Demos, 131-142.

Monge, PR \& Contractor, NS (2001). Emergence of Communication Networks, i: Jablin, FM \& Putnam, LL (eds'). The new handbook of organizational communication: Advances in theory, research and methods. Thousand Oaks, CA : Sage, 440-502.

Perri, Dr 6 (2004). Your friendship networks - are they any of the government's business?, i: McCarthy, H; Miller, P \& Skidmore, P (eds'). Network Logic. What governs in an interconnected world? London : Demos, 131-142.

Poulsen, A (2004). Aktivitetsrummet unge piger i Vollsmose Bibliotek, i: Kragh-Schwarz, B \& Poulsen AK. Biblioteket - en port til det danske samfund. Eksempler til inspiration. København : Biblioteksstyrelsen, 33-34.

Rogers, EM \& Kincaid, DL (1981). Communication Networks: Toward a New Paradigm for Research. New York : Free Press.

Rogers, EM (1986). Communication Technology: The New Media in Society. New York : Free Press.

Rogers, EM (1995). Diffusion of Innovations. New York: The Free Press.

Sampson, RJ (2004). Networks and neighbourhoods, i: McCarthy, H; Miller, P \& Skidmore, P (eds'). Network Logic. What governs in an interconnected world? London : Demos, 157-166. 
Seidenfaden, S (2004). Ingen integration uden kontakt - biblioteket som netværksorganisator og tovholder, i: Kragh-Schwarz, B \& Poulsen AK. Biblioteket - en port til det danske samfund. Eksempler til inspiration. København : Biblioteksstyrelsen, 3-4.

Simmel, G (1908/1955). Conflict and the web of group affiliations. Glecoe, IL : Free Press.

Skot-Hansen, D (2002a). The public library between integration and cultural diversity. Scandinavian Public Library Quarterly, 35 (1), 12-13.

Skot-Hansen, D (2002b) The public library in the service of the civil society. Scandinavian Public Library Quarterly, 32 (3), 12-13.

Skot-Hansen, D (2002c). The hybrid library - an answer to the challenges of reflexive society? Scandinavian Public Library Quarterly, 35 (4), 12-13.

Skot-Hansen, D (2002d). Danish Cultural Policy from monoculture towards cultural diversity. International Journal of Cultural Policy, 8 (2), 197-210.

Stephenson, K (2004). Towards a theory of government, i: McCarthy, H; Miller, P \& Skidmore, P (eds'). Network Logic. What governs in an interconnected world? London : Demos, 37-48.

Stouffer, SA; Suchman, E; Devinney, L; Star, S \& Williams, R (1949). The American Soldier. Princeton : Princeton University Press.

Sundhedsstyrelsen (2002). Netvaerksstrategi i praksis. Principper og Erfaringer. København : Sundhedsstyrelsen.

Qvortrup, L (2003). Fra netværk til kompleksitet: Netværksbegrebet - et forlegenhedsbegreb, i Bondebjerg, I \& Bank, H. Modinet-Temanummer Netvarksbegrebet og Netvarkssamfundet. Working Paper No. 4, København : Modinet, 7-36.
Van Dijk, JAGM (2001). Netwerken als Zenuwstelsel van onze Maatschappij. Tijdschrift voor Communicatiewetenschap, 30, 37-54.

Vedel Larsen, B (2004). Godnat Gellerup - et forsøg på at finde Danmark. Debatteater, i: Kragh-Schwarz, B \& Poulsen AK. Biblioteket - en port til det danske samfund. Eksempler til inspiration. København : Biblioteksstyrelsen, 30-32.

Weisbjerg, B \& Elbeshausen, H (2004). Nær ved, tæt på og sammen med. Bibliotekaren som streetwalker - model for biblioteksarbejde med etniske minoriteter, i: Kragh-Schwarz, B \& Poulsen AK. Biblioteket - en port til det danske samfund. Eksempler til inspiration. København : Biblioteksstyrelsen, 7-9.

Wigand, RT (1988). Communication Network Analysis: History and Overview, i: Goldhaber, G. and Barnett, G. (eds'). Handbook of Organizational Communication. Norwood, NJ : Ablex Publishing Corp., 319-358.

Yum, JO (1984). Network Analysis, i: Gudykunst, W \& Kim, Y (eds'). Methods or intercultural communication research. Beverly Hills, CA : Sage, 95116.

Yum, JO (1989). The Communication Network Paradigm and Intercultural Communication, i: Dervin, B; Grossberg, L; O'Keefe \& Wartells, E (ed's.). Rethinking Communication. Volume 2, Paradigm Exemplars. Newbury Park : Sage, 486-498.

Ørom, A (2004). Biblioteker og kunstmuseer som kulturarvsinstitutioner. Biblioteksarbejde nr. 67/68, 29-44.

Roy Langer, ph.d., er professor ved Institut for Kommunikation, Journalistik og Datalogi, Roskilde Universitetscenter.royla@ruc.dk 